\title{
PENGARUH PEMBELAJARAN MATEMATIKA REALISTIK TERHADAP KEMAMPUAN KOMUNIKASI MATEMATIS SISWA KELAS VII SMP
}

\author{
Ida Wati Sihotang \\ Universitas Katolik Santo Thomas, Medan; \\ watiida103@gmail.com
}

\begin{abstract}
Abstrak. Penelitian ini bertujuan: (1) Untuk mengetahui apakah pendekatan Pembelajaran Matematika Realistik berpengaruh terhadap kemampuan komunikasi matematis siswa. (2) Untuk mengetahui apakah peningkatan kemampuan komunikasi matematis siswa dengan pendekatan Pembelajaran Matematika Realistik lebih tinggi dari pembelajaran konvensional. Jenis penelitian ini adalah penelitian eksperimen dengan menggunakan pretest-postest control group design. Populasi penelitian adalah seluruh siswa kelas VII SPM YPAK Galang yang terdiri dari tiga kelas. Sampel penelitian dipilih menggunakan teknik simple random sampling, sehingga diperoleh kelas VII-A sebagai kelas eksperimen dan kelas VII-C sebagai kelas kontrol dengan masingmasing jumlah 37 siswa. Data yang digunakan dalam penelitian ini adalah data kuantitatif. Berdasarkan analisis data penelitian, diperoleh hasil sebagai berikut: (1) hasil analisis regesi diperoleh persamaan $\widehat{Y}=$ 36,945+1,003X. Dan dari hasil korelasi diperoleh bahwa Pembelajaran Matematika Realistik berpengaruh positif dengan koefisien korelasi sebesar 0,944 dan koefisien determinasi sebesar 89,1\%. Sehingga dapat disimpulkan bahwa Pembelajaran Matematika Realistik berpengaruh terhadap kemampuan komunikasi matematis siswa. ; (2) hasil analisis uji-t dengan nilai thitung $=4,489$ dan $t_{\text {tabel }}=1,666$ yang artinya thitung $>t_{\text {tabel }}$, maka hipotesis Ho ditolak. Sehingga dapat disimpulkan bahwa kemampuan komunikasi matematis siswa yang diajar dengan Pembelajaran Matematika Realistik lebih tinggi daripada kemampuan komunikasi matematis siswa yang diajar dengan pembelajaran konvensional.
\end{abstract}

Kata Kunci. Matematika realistik, kemampuan komunikasi

Abstract. This study aims: (1) To find out whether the Realistic Mathematics Learning approach influences students' mathematical communication skills. (2) To find out whether the increase in students' mathematical communication

Cartesius: Jurnal Pendidikan Matematika Vol. 2, No. 1

CProdi Pendidikan Matematika Universitas Katolik Santo Thomas 
skills with the Realistic Mathematics Learning approach is higher than conventional learning. This type of research is experimental research using pretest-posttest control group design. The study population was all VII grade students of YPAK Galang SPM consisting of three classes. The research sample was selected using simple random sampling technique, so that the VII-A class as the experimental class and VII-C class as the control class were obtained with 37 students each. The data used in this study are quantitative data. Based on the analysis of the research data, the following results are obtained: (1) the results of the regression analysis obtained by the equation $(Y)^{\wedge}=36,945+$ 1,003X. And from the results of the correlation obtained that Realistic Mathematics Learning has a positive effect with a correlation coefficient of 0.944 and a coefficient of determination of $89.1 \%$. So it can be concluded that Realistic Mathematics Learning influences students' mathematical communication skills.; (2) the results of the t-test analysis with the value of $t$ count $=4.489$ and $t$ table $=1.666$ which means $t$ count $>t$ table, then the hypothesis $H o$ is rejected. So it can be concluded that the mathematical communication skills of students taught by Realistic Mathematics Learning are higher than the mathematical communication skills of students who are taught by conventional learning.

Keywords. Realistic mathematics, communication skills

\section{PENDAHULUAN}

Salah satu peran pendidikan adalah mengembangkan potensi Sumber Daya Manusia (SDM) yang berpengaruh pada perkembangan Ilmu Pengetahuan dan Teknologi (IPTEK). Pendidikan sangatlah penting sebab pendidikan merupakan suatu lembaga yang berusaha untuk mambangun masyarakat dan watak bangsa secara berkesinambungan untuk membina mental, dan kepribadian dalam rangka membentuk manusia yang seutuhnya. Salah satu mata pelajaran yang penting dalam bidang pendidikan adalah matematika.

Matematika merupakan salah satu mata pelajaran yang wajib dipelajari oleh siswa mulai dari tingakat sekolah dasar sampai tingkat perguruan tinggi. Melalui proses pembelajaran matematika guru dapat melihat bahwa sejauh mana kemampuan yang dimililiki oleh setiap siswa. Sebagaimana yang tertulis dalam National Council of Teachers of Mathematics (NCTM, 2015) menyatakan bahwa ada lima kemampuan matematis yang seharusnya dimiliki siswa salah satunya adalah yaitu: (1) kemampuan berkomunikasi;

Cartesius: Jurnal Pendidikan Matematika Vol. 2, No. 1

CProdi Pendidikan Matematika Universitas Katolik Santo Thomas 
(2) kemampuan bernalar; (3) kemampuan pemecahan masalah memecahkan masalah; (4) kemampuan mengaitkan ide; (5) kemampuan merepresentasikan ide-ide [1]. Jadi, salah satu bagian dari kemampuan matematis yaitu kemampuan komunikasi.

Kemampuan komunikasi matematis adalah salah satu dari kemampuan dalam matematika yang harus dikuasai oleh siswa. Dalam berkomunikasi matematis, terdapat proses penyampaian ide atau gagasan matematika baik secara lisan atau tulisan sehingga dapat menciptakan pemahaman [2]. Komunikasi matematis adalah suatu peristiwa saling berdialog yang terjadi di lingkungan kelas, dimana terjadi pengalihan pesan, dan pesan yang dialihkan berisikan tentang materi matematika yang di pelajari siswa, misalnya berupa konsep, rumus, atau strategi penyelesaian suatu masalah.

Sullivan \& Mousley memandang kemampuan komunikasi matematik sebagai kemampuan siswa dalam bercakap, menjelaskan, menggambarkan, mendengarkan, menanyakan, mengklarifikasi, bekerja sama, berbagi , menulis, dan akhirnya melaporkan apa yang telah dipelajari [3]. Sedangkan menurut Sumarmo, ada beberapa indikator kemampuan komunikasi matematika yaitu: 1. Menghubungkan benda nyata, gambar, dan diagram ke dalam ide matematika. 2. Menjelaskan ide, situasi dan relasi matematika, secara lisan atau tulisan dengan benda nyata, gambar, grafik dan aljabar. 3. Menyatakan peristiwa sehari-hari dalam bahasa atau simbol matematika. 4 . Mendengarkan, berdiskusi, dan menulis tentang matematika. 5. Membaca dengan pemahaman suatu presentasi matematika tertulis [4].

Berdasarkan hasil laporan survei Programme for International Student Assessment (PISA, 2015) yang merupakan program organisasi kerjasama ekonomi dan pembangunan dunia (OECD) menunjukkan bahwa pada tahun 2016, prestasi siswa Indonesia berada pada posisi 67 dari 74 negara yang disurvei. Skor rata-rata kemampuan matematis siswa Indonesia yaitu 386 di bawah skor rata-rata kemampuan matematis siswa di negara lainnya yaitu 490. Aspek yang dinilai dalam PISA adalah kemampuan pemahaman, pemecahan masalah (problem solving), kemampuan penalaran (reasoning), dan kemampuan komunikasi (communication).

Cartesius: Jurnal Pendidikan Matematika Vol. 2, No. 1

CProdi Pendidikan Matematika Universitas Katolik Santo Thomas 
Data lain sebagai pembanding dapat dilihat melalui Ujian Nasional (UN). Pada tingkat SMP salah satu mata pelajaran yang diujikan adalah matematika. Pada pelaksanaan UN tahun 2016, mata pelajaran matematika mengalami penurunan besar. Perubahannya dari 56,28 pada tahun 2015, kini nilainya menjadi 50,24. Terjadi penurunan sebesar 6,04 poin. Dari pernyataan tersebut diketahui bahwa kemampuan siswa SMP di Indonesia dalam mengerjakan soal masih rendah.

Berdasarkan hasil wawancara dengan Bapak H. Manurung S.Pd guru mata pelajaran Matematika di SMP SWASTA YPAK Galang, diperoleh informasi bahwa pembelajaran matematika yang dilakukan di sekolah belum sepenuhnya dapat meningkatkan kemampuan komunikasi matematis siswa. Hal ini dapat diketahui berdasarkan nilai sehari-hari, dimana siswa kelas VII A, VII B, dan VII C, memperoleh nilai rata- rata berturut-turut 72, 70, dan 67 sehingga nilai rata-rata sebesar 70 yang belum memenuhi Kriteria Ketuntasan Minimum (KKM) yang seharusnya 75. Selain nilai, hal yang mendukung kemampuan komunikasi matematis siswa SMP SWASTA YPAK Galang rendah yaitu sikap siswa. Siswa cenderung pasif dalam pembelajaran, tidak bertanya serta tidak mengemukakan pendapat. Masih banyak siswa yang kurang memperhatikan penjelasan guru, bahkan ada siswa tidak mengikuti pembelajaran dengan baik, serta bermain dan berbicara dengan teman sebangkunya.

Pada kenyataannya, beberapa praktek di lapangan menunjukkan bahwa dalam kegiatan pembelajaran matematika, guru masih kurang memberikan kesempatan kepada siswa untuk menyampaikan ide atau pendapatnya. Dengan kata lain guru lebih aktif daripada siswa sehingga siswa tidak terlatih dalam mengembangkan kemampuan komunikasi matematikanya [5]. Rendahnya kemampuan komunikasi matematis siswa diakibatkan oleh pembelajaran matematika yang umumnya bersifat konvensional dengan karakteristik berpusat pada guru. Siswa tidak dilatih bagaimana mengkomunikasikan pemahaman mereka terhadap materi yang sudah mereka pelajari. Sehubungan dengan itu, pemanfaatan konteks nyata dipandang sangat relevan digunakan dalam membangun pengetahuan matematika siswa. Dengan demikian, perlu penerapan salah satu Cartesius: Jurnal Pendidikan Matematika Vol. 2, No. 1 CProdi Pendidikan Matematika Universitas Katolik Santo Thomas 
pendekatan pembelajaran yang tepat untuk meningkatkan komunikasi matematis siswa yaitu pendekatan Pembelajaran Matematika Realistik (PMR).

Pembelajaran Matematika Realistik (PMR) merupakan pendekatan pembelajaran yang menggunakan situasi dunia nyata atau suatu konteks yang real dan pengalaman siswa sebagai titik tolak belajar matematika. Pembelajaran matematika realistik memiliki karakteristik dan prinsip yang memungkinkan siswa dapat berkembang secara optimal, adanya masalah kontekstual yang dapat mengaitkan konsep matematika dengan kehidupan nyata, dengan pembuatan model yang dapat memudahkan siswa untuk berkontribusi dalam menyelesaikan maslah, adanya interaktivitas baik sesama siswa maupun dengan guru yang dapat membantu siswa yang lemah untuk memahami konsep sedangkan bagi siswa yang pandai dapat meningkatkan kemampuan dalam memberi penjelasan, tanggapan, dll. [6].

Dalam pembelajaran matematika realistik, sebelum belajar matematika dalam sistem yang formal, siswa dibawa kedalam situasi informal terlebih dahulu. Siswa diperkenalkan dengan permasalahan yang dialami. Dalam menyelesaikan masalah siswa dapat bekerja sendiri atau bisa juga bekerja kelompok. Kemudian siswa membuat model sendiri berdasarkan pengalaman sebelumnya atau mendiskusikan bersama dengan teman sekelompok. Pendekatan Pembelajaran Matematika Realistik (PMR) dimulai dari sesuatu yang riil sehingga siswa dapat terlibat dalam proses pembelajaran secara bermakna. Peran guru hanya sebagai pembimbing dan fasilitator bagi siswa. Siswa adalah individu yang mempunyai potensi untuk mengembangkan pengetahuan dalam dirinya.

Pembelajaran Matematika Realistik (PMR) baik untuk diterapkan dalam pembelajaran matematika. Berdasarkan penelitian yang dilakukan oleh Ayu Handayani, Mukhni, dan Nilawasti (2014) dengan judul Kemampuan komunikasi matematis siswa kelas VII MTsN Lubuk Buaya Padang menggunakan pendekatan Pembelajaran Matematika Realistik (PMR) diperoleh hasil bahwa siswa memperoleh nilai rata-rata sebesar 68,75 dengan presentase siswa yang tuntas sebanyak 45,26\%. Sedangkan hasil kuis

Cartesius: Jurnal Pendidikan Matematika Vol. 2, No. 1

CProdi Pendidikan Matematika Universitas Katolik Santo Thomas 
matematika yang kedua, siswa memperoleh nilai rata-rata sebesar 80,27 dengan presentase siswa yang tuntas sebanyak 73,81\%. Peningkatan hasil kuis siswa sebesar 11,52 dan presentase peningkatan jumlah siswa yang tuntas sebanyak $28,55 \%$.

Berdasarkan hasil penelitian yang ditunjukkan di atas maka dapat dilihat bahwa Pembelajaran Matematika Realistik dapat atau layak untuk diterapkan dengan melihat tingkat keberhasilan yang diperoleh dalam suatu penelitian. Oleh karena itu perlu dilakukan penelitian judul Pengaruh Pembelajaran Matematika Realistik (PMR) terhadap Kemampuan Komunikasi Matematis Siswa Kelas VII SMP.

\section{METODE}

Pendekatan yang digunakan dalam penelitian ini adalah penelitian kuantitatif dengan metode penelitian quasi eksperimen dengan Pretest-Posttest Control Group Design. Penelitian ini dilaksanakan di SMP YPAK Galang Tahun pembelajaran 2017/2018.

Populasi dalam penelitian ini adalah seluruh siswa kelas VII di SMP YPAK Galang semester ganjil pada Tahun Ajaran 2017/2018. Jumlah kelas ada sebanyak tiga kelas dengan rata-rata jumlah siswa sebanyak 37 orang per kelas. Teknik pengambilan sampel menggunakan simple random sampling (sampel sederhana). Setelah dilakukan simple random sampling dari tiga kelas yang ada maka diperoleh sebagai sampel adalah kelas VII-A sebagai siswa kelas eksperimen dan siswa kelas VII-B sebagai kelas kontrol, seperti pada gambar 1 dibawah ini:

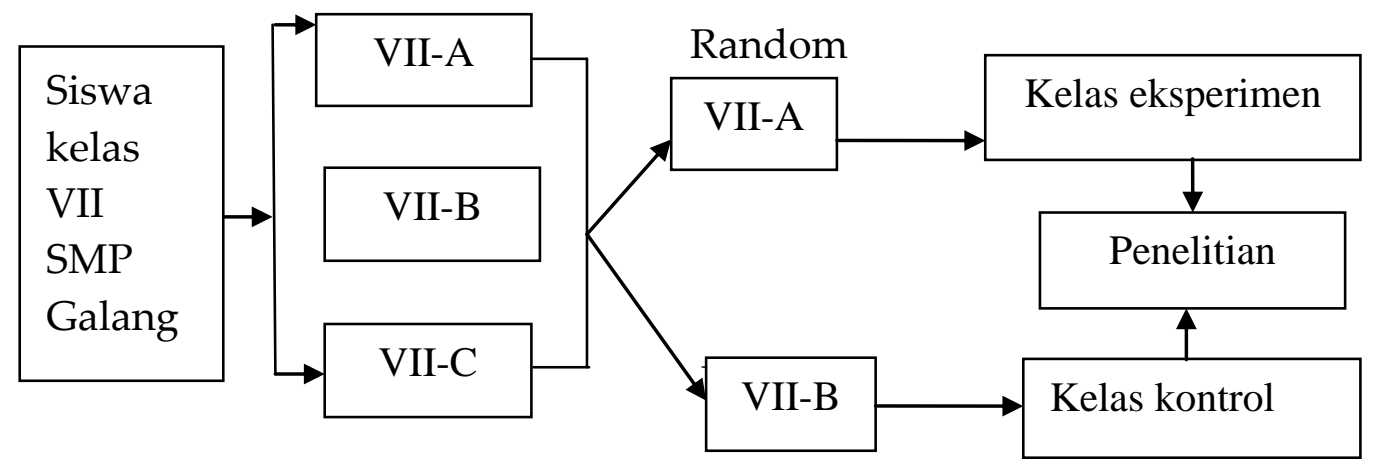

Gambar 1. Teknik Pengambilan Sampel

Cartesius: Jurnal Pendidikan Matematika Vol. 2, No. 1

(CProdi Pendidikan Matematika Universitas Katolik Santo Thomas 
Jenis data yang digunakan adalah data kuantitatif. Alat yang digunakan untuk mengukur kemampuan komukasi matematis siswa yaitu tes. Tes yang dilakukan adalah tes tertulis berupa soal uraian. Adapun tes yang digunakan berupa tes awal pre-test dan test akhir post-test yang diberikan kepada kelas eksperimen dan kelas kontrol. Untuk memperoleh data yang diperlukan dalam penelitian, penelitian menggunakan pre-test untuk mengetahui seberapa besar kemampuan awal siswa. Sedangkan untuk mengetahui perbedaan kemampuan masing-masing siswa pada mata pelajaran matematika menggunakan post-test setelah menggunakan pendekatan realistik dan kemampuan siswa yang mendapat perlakuan dengan menggunakan metode pembelajaran konvensional.

Teknik analisis data yang digunakan dalam penelitian ini adalah teknik analisis dengan uji perbedaan dan rata-rata populasi menggunakan uji-t dengan taraf signifikans $\alpha=0,05$ untuk menguji hipotesis. Sebelum melakukan uji-t, terlebih dahulu harus dilakukan uji prasyarat analisis yaitu uji normalitas dan uji homogenitas dengan bantuan aplikasi SPSS 21 for windows. Hipotesis dan jenis statistik yang digunakan dalam penelitian disajikan pada tabel berikut:

Tabel 3. Keterkaitan Permasalahan, Hipotesis dan Jenis Uji Statistik

\begin{tabular}{clcl}
\hline No. & \multicolumn{1}{c}{ Permasalahan yang diteliti } & Hipotesis & Jenis Uji Statistik \\
\hline 1. & Apakah pendekatan Pembelajaran & 1 & Analisis regresi \\
& Matematika Realistik (PMR) \\
berpengaruh terhadap kemampuan & & $\begin{array}{l}\text { linier sederhana } \\
\text { dan korelasi. }\end{array}$ \\
komunikasi matematis siswa? & & \\
\hline 2. & Apakah peningkatan kemampuan & 2 & Uji-t dan Gain \\
& komunikasi matematis siswa yang & & Ternormalisasi \\
& diajarkan dengan Pembelajaran \\
& Matematika Realistik (PMR) lebih \\
tinggi daripada pembelajaran & & \\
& & \\
Konvensional?
\end{tabular}

Cartesius: Jurnal Pendidikan Matematika Vol. 2, No. 1

CProdi Pendidikan Matematika Universitas Katolik Santo Thomas 


\section{HASIL DAN PEMBAHASAN}

\section{HASIL PENELITIAN}

Data yang dideskripsikan dalam penelitian ini yaitu hasil tes kemampuan komunikasi matematis siswa. Secara umum deskripsi kedua kelompok data kemampuan komunikasi matematis siswa disajikan pada tabel berikut ini:

Tabel 4. Deskripsi Mean dan Standar Deviasi Pretes Kemampuan Komunikasi Matematis Siswa Kelompok Eksperimen dan Kontrol

\begin{tabular}{ccccccc}
\hline \multirow{2}{*}{$\begin{array}{c}\text { Statis } \\
\text { tik }\end{array}$} & \multicolumn{2}{c}{ Pretes } & \multicolumn{2}{c}{ Postes } & \multicolumn{2}{c}{ N-Gain } \\
\cline { 2 - 7 } & PMR & Konvesional & PMR & Konvesional & PMR & Konvensional \\
\hline $\mathbf{N}$ & 37 & 37 & 37 & 37 & 37 & 37 \\
$\begin{array}{r}\text { Rata- } \\
\text { rata }\end{array}$ & 37,84 & 36,62 & 74,89 & 54,84 & 0,64 & 0,36 \\
$\begin{array}{c}\text { Std. } \\
\text { Dev }\end{array}$ & 16,81 & 17,67 & 17,86 & 19,77 & 0,19 & 0,17 \\
\hline
\end{tabular}

Berdasarkan tabel 4 di atas diperoleh bahwa peningkatan pembelajaran yang menggunakan pembelajaran realistik sebelum proses pembelajaran nilai rata-rata sebesar 37,84 dan setelah dilaksanakan pendekatan pembelajaran realistik menjadi 74,89 (peningkatan sebesar 0,64). Sedangkan untuk pembelajaran konvesional diperoleh nilai rata-rata sebelum pembelajaran adalah 36,62 dan setelah pembelajaran menjadi 54,84 (peningkatan sebesar $0,36)$.

Secara deskriptif ada beberapa kesimpulan yang dapat dilhat dari data kemampuan komunikasi matematis siswa pada tabel 4 di atas yaitu:

1. Secara keseluruhan nilai rerata pretes kemampuan komunikasi matematis siswa pada kelas eksperimen sebesar $(37,84)$ terlihat lebih tinggi dibandingkan dengan nilai rerata pretes pada kelas kontrol sebesar $(36,62)$.

2. Secara keseluruhan nilai rerata postest kemampuan komunikasi matematis siswa pada kelas eksperimen sebesar $(74,89)$ terlihat lebih tinggi dibandingkan dengan nilai rerata postes pada kelas kontrol sebesar $(54,84)$.

Cartesius: Jurnal Pendidikan Matematika Vol. 2, No. 1

CProdi Pendidikan Matematika Universitas Katolik Santo Thomas 
3. Rerata N-Gain kemampuan komunikasi matematis siswa pada kelas eksperimen sebesar $(0,64)$ lebih tinggi dibandingkan dengan siswa pada kelas kontrol sebesar $(0,36)$.

Langkah selanjutnya akan dilakukan pengujian secara statistik inferensial untuk mengetahui kebenaran dari kesimpulan diatas dengan uji regresi sederhana dan uji-t.

Analisis regresi linear sederhana adalah hubungan secara linear antara satu variabel independen $(\mathrm{X})$ dan variabel dependen $(\mathrm{Y})$. Berdasarkan hasil olah data maka diperoleh persamaan regresi sebagai berikut:

Tabel 5. Hasil Analisis Regresi Linear Sederhana

\begin{tabular}{|c|c|c|c|c|c|c|}
\hline & \multirow[t]{2}{*}{ Model } & \multicolumn{2}{|c|}{$\begin{array}{c}\text { Unstandardized } \\
\text { Coefficients }\end{array}$} & \multirow{2}{*}{$\begin{array}{c}\begin{array}{c}\text { Standardized } \\
\text { Coefficients }\end{array} \\
\text { Beta }\end{array}$} & \multirow{2}{*}{$\begin{array}{c}\mathrm{T} \\
\mathrm{B}\end{array}$} & \multirow{2}{*}{$\begin{array}{l}\text { Sig. } \\
\text { Std. } \\
\text { Error }\end{array}$} \\
\hline & & B & Std. Error & & & \\
\hline \multirow{2}{*}{1} & (Constant) & 36,945 & 2,451 & & 15,073 & 0,000 \\
\hline & Pretest & 1,003 & 0,059 & 0,944 & 16,904 & 0,000 \\
\hline
\end{tabular}

Berdasarkan tabel 5 diperoleh nilai konstanta adalah 36,945 sedangkan nilai koefisien regresi sebesar 1,003. Persamaan untuk regresi yang digunakan adalah $\hat{Y}=a+b X$ dengan a merupakan konstanta dan b merupakan koefisien regresi. Persamaan yang diperoleh sebagai berikut:

$$
\widehat{Y}=36,945+1,003 \mathrm{X}
$$

Dari hasil analisis di atas diperoleh thitung $=16,904$ dan diperoleh nilai signifikansinya $=0,000<0,05$ atau $\mathrm{H}_{0}$ ditolak. Nilai tersebut jika dibandingkan dengan nilai tabel pada $\propto=0,05$ dengan $\mathrm{df}=\mathrm{N}-2=74-2=72$ yaitu sebesar 1,666 (thitung $>$ tabel $=16,904>1,666$ ) maka $H_{0}$ ditolak. Dengan demikian model pembelajaran realistik berpengaruh positif terhadap kemampuan komunikasi matematis siswa. Untuk menentukan taraf signifikansi atau linearitas dan regresi maka disajikan pada tabel hasil uji signifikan berikut:

Tabel 6. Hasil Uji Nilai Signifikan

\begin{tabular}{lllllll}
\hline & \multicolumn{6}{c}{ ANOVA $^{\text {Ma }}$} \\
\cline { 2 - 6 } Model & Sum of Squares & Df & Mean Square & F & Sig. \\
\hline \hline
\end{tabular}

Cartesius: Jurnal Pendidikan Matematika Vol. 2, No. 1

CProdi Pendidikan Matematika Universitas Katolik Santo Thomas 


\begin{tabular}{|c|c|c|c|c|c|c|}
\hline 1 & Regression & 5569.784 & 1 & 5569.784 & 15.682 & $\begin{array}{r}0.000 \\
b\end{array}$ \\
\hline & Residual & 25572.757 & 72 & 355.177 & & \\
\hline & Total & 31142.541 & 73 & & & \\
\hline
\end{tabular}

a. Dependent Variable: kelas_eksperimen

b. Predictors: (Constant), kelas_kontrol

Kriteria dapat ditentukan berdasarkan uji nilai signifikansi (sig), dengan ketentuan jika nilai sig<0,05. Berdasarkan tabel 6 diperoleh nilai signifikansinya $=0,000<0,05$, berarti persamaan regresi di atas linear atau terdapat pengaruh yang signifikan pada penerapan pendekatan Pembelajaran Matematika Realistik (PMR) terhadap kemampuan komunikasi matematis siswa.

Untuk menyatakan apakah garis yang diperoleh cukup baik untuk menggambarkan hubungan antara peubah bebas $(X)$ dengan peubah tak bebas (Y) dapat dilakukan pengujian bentuk model yang digunakan dan keeratan hubungannya (korelasi) untuk menyatakan ketepatan dan ketelitian persamaan garis regresi yang diperoleh. Koefisien korelasi adalah koefisien yang memperlihatkan tingkat keeratan hubungan antara variabel $\mathrm{X}$ dan $\mathrm{Y}$.

Tabel 7. Hasil Analisis Korelasi pada Kelas Eksperimen

\begin{tabular}{rrrrr}
\hline Model & $\mathbf{R}$ & $\begin{array}{c}\mathbf{R} \\
\text { Square }\end{array}$ & $\begin{array}{c}\text { Adjusted } \mathbf{R} \\
\text { Square }\end{array}$ & $\begin{array}{l}\text { Std. Error of } \\
\text { the Estimate }\end{array}$ \\
\hline 1 & $0,944^{\text {a }}$ & 0,891 & 0,888 & 5,985 \\
\hline
\end{tabular}

Berdasarkan tabel 7 di atas, diperoleh korelasi positif antara kelompok Pembelajaran Matematika Realistik (PMR) dengan kemampuan komunikasi matematis siswa dengan koefisien korelasi sebesar 0,944. Besarnya nilai koefisien korelasi memiliki kriteria kuat. Koefisien korelasi determinasi yang merupakan koefisien penentu didapat sebesar 0,891. Nilai tersebut menunjukkan bahwa keberhasilan siswa mengikuti pembelajaran dengan pendekatan Pembelajaran Matematika Realistik (PMR) menentukan besarnnya perolehan kemampuan komunikasi matematis siswa sebesar $89,1 \%$.

Cartesius: Jurnal Pendidikan Matematika Vol. 2, No. 1

CProdi Pendidikan Matematika Universitas Katolik Santo Thomas 
Pengujian hipotesis dilakukan dengan menggunakan uji-t dengan bantuan SPSS 21 for windows menggunakan indenpendent-sample t-test. Hasil perhitungan uji-t terhadap data N-Gain kemampuan komunikasi matematis siswa dapat dilihat pada tabel 8 berikut:

Tabel 8. Hasil Uji-t Kemampuan komunikasi Matematis Siswa

\begin{tabular}{cccc}
\hline Pendekatan & \multicolumn{3}{c}{ Kemampuan Komunikasi Matematis } \\
\cline { 2 - 4 } Pembelajaran & T & Sig. & Ho \\
\hline PMR dan & 4,489 & 0.000 & Ditolak \\
Konvesional & & & \\
\hline
\end{tabular}

Berdasarkan tabel 8 diatas disimpulkan bahwa tHitung sebesar 4,489 dan berdasarkan tabel $\mathrm{t}$ diperoleh tabel sebesar 1,666. Hal ini menunjukkan bahwa $t_{\text {Hitung }}>$ t tabel $\left._{(4,489}>1,666\right)$ dan karena diperoleh nilai signifikan lebih kecil dari $\alpha=0,05 \quad(0,000<0,05)$. Sehingga hipotesis $\mathrm{H}_{\mathrm{o}}$ ditolak dan $\mathrm{H}_{\mathrm{a}}$ diterima, maka disimpulkan rerata peningkatan kemampuan komunikasi matematis siswa yang memperoleh Pembelajaran Matematika Realistik (PMR) lebih tinggi daripada siswa yang mendapatkan pembelajaran konvensional.

Pada tabel diatas dapat dilihat bahwa berdasarkan kelompok signifikance (sig) lebih kecil dari 0,05, sihingga $\mathrm{H}_{0}$ ditolak. Dengan demikian, ada peningkatan yang signifikan kemampuan komunikasi matematis siswa baik dikelas eksperimen maupun kelas kontrol. Namun adanya perbedaan peningkatan itu harus dibuktikan dengan uji statistik dengan menggunakan uji-t dengan independent sample t-test Kriteria pengujian yang digunakan adalah jika nilai signifikance (sig) lebih besar dari $\propto=0,05$, maka $\mathrm{H}_{a}$ diterima sedangkan $\mathrm{H}_{0}$ ditolak. Hasil perhitungan uji-t terhadap nilai posttes kemampuan komunikasi matematis siswa dapat dilihat pada tabel berikut:

Tabel 9. Hasil Uji Singnifikan Peningkatan Kemampuan Komunikasi Matematis

\begin{tabular}{ccccc}
\hline $\begin{array}{c}\text { Kelompok } \\
\text { data }\end{array}$ & N & Mean & Std. Deviation & Std. Error Mean \\
\hline kelas_eks & 37 & 0,6459 & 0,19961 & 0,03282 \\
kelas_kont & 37 & 0,3652 & 0,17519 & 0,02880 \\
\hline
\end{tabular}

$\mathrm{H}_{0}$ : Tidak ada peningkatan kemampuan komunikasi matematis siswa baik di

Cartesius: Jurnal Pendidikan Matematika Vol. 2, No. 1

CProdi Pendidikan Matematika Universitas Katolik Santo Thomas 
kelas eksperimen maupun di kelas kontrol.

Berdasarkan hasil pengujian hipotesis yang berkenaan dengan kemampuan komunikasi matematis siswa yang diperoleh melalui pengujian statistik pada skor tes kemampuan komunikasi matematis siswa disajikan pada tabel 10 berikut:

Tabel 10. Rangkuman Hasil Pengujian Hipotesis Penelitian KemampuanKomunikasi Matematis Siswa

\begin{tabular}{|c|c|c|c|c|}
\hline No. & $\begin{array}{c}\text { Permasalahan yang } \\
\text { Diteliti }\end{array}$ & $\begin{array}{c}\text { Uji } \\
\text { Statistik }\end{array}$ & $\begin{array}{l}\text { Penguji } \\
\text { an } \mathrm{Ha}\end{array}$ & Hasil Pengujian \\
\hline 1 & $\begin{array}{l}\text { Apakah terdapat } \\
\text { pengaruh } \\
\text { pendekatan } \\
\text { Pembelajaran } \\
\text { Matematika Realistik } \\
\text { (PMR) terhadap } \\
\text { kemampuan } \\
\text { komunikasi } \\
\text { matematis siswa? }\end{array}$ & $\begin{array}{c}\text { Regresi } \\
\text { Linier } \\
\text { Sederha } \\
\text { na dan } \\
\text { Korelasi }\end{array}$ & $\begin{array}{c}\text { Terima } \\
\mathrm{Ha}_{\mathrm{a}}\end{array}$ & $\begin{array}{l}\text { Terdapat pengaruh } \\
\text { pendekatan } \\
\text { Pembelajaran } \\
\text { Matematika Realistik } \\
\text { (PMR) terhadap } \\
\text { kemampuan } \\
\text { komunikasi matematis } \\
\text { siswa. }\end{array}$ \\
\hline 2 & $\begin{array}{l}\text { Apakah peningkatan } \\
\text { kemampuan } \\
\text { komunikasi } \\
\text { matematis siswa } \\
\text { yang memperoleh } \\
\text { pendekatan } \\
\text { Pembelajaran } \\
\text { Matematika Realistik } \\
\text { (PMR) lebih tinggi } \\
\text { dibandingkan } \\
\text { dengan siswa yang } \\
\text { memperoleh model } \\
\text { pembelajaran } \\
\text { konvesional? }\end{array}$ & $\begin{array}{l}\text { Uji t dan } \\
\text { N-Gain }\end{array}$ & $\begin{array}{c}\text { Terima } \\
\mathrm{Ha}_{\mathrm{a}}\end{array}$ & $\begin{array}{l}\text { Peningkatan } \\
\text { kemampuan } \\
\text { komunikasi matematis } \\
\text { siswa yang } \\
\text { memperoleh } \\
\text { pendekatan } \\
\text { Pembelajaran } \\
\text { Matematika Realistik } \\
\text { (PMR) lebih tinggi } \\
\text { dibandingkan dengan } \\
\text { siswa yang } \\
\text { memperoleh model } \\
\text { pembelajaran } \\
\text { konvesional. }\end{array}$ \\
\hline
\end{tabular}

\section{PEMBAHASAN}

Jika diamati dari koefisien variabel, penelitian ini dapat dinyatakan bahwa variabel pendekatan pembelajaran realistik dengan kemampuan komunikasi matematis siswa memiliki korelasi yang positif. Hasil analisis yang diperoleh

Cartesius: Jurnal Pendidikan Matematika Vol. 2, No. 1

CProdi Pendidikan Matematika Universitas Katolik Santo Thomas 
memberikan gambaran bahwa ternyata pendekatan pembelajaran realistik berpengaruh terhadap kemampuan komunikasi matematis siswa. Berdasarkan hasil penelitian maka diperoleh temuan penelitian sebagai berikut:

1. Hasil analisisi regresi diperoleh bahwa berpengaruh model Pembelajaran Matematika Realistik (PMR) dan model konvensional berpengaruh positif dengan koefisien korelasi 0,944 dan koefisien determinasi sebesar 89,1\% sedangkan sisanya dipengaruhi faktor lain.

2. Hasil analisis uji perbedaan dua rerata menggunakan uji-t diperoleh nilai signifikan rerata peningkatan komunikasi matematis siswa kelas eksperimen dan kelas kontrol adalah 0,000<0,05, maka hipotesis Ho ditolak. Sehingga dapat disimpulkan bahwa kemampuan komunikasi matematis siswa yang memperoleh pembelajaran pendekatan Pembelajaran Matematika Realistik (PMR) lebih tinggi daripada siswa yang memperoleh pembelajaran model konvesional.

\section{KESIMPULAN}

Berdasarkan uraian yang telah dikemukakan pada bab sebelumnya, maka dapat dikemukakan beberapa simpulan dari penelitian ini, yaitu:

1. Berdasarkan hasil analisis korelasi dan regresi diperoleh bahwa penerapan pembelajaran realistik berpengaruh positif dengan koefisien korelasi 0,944 dan koefisien determinasi sebesar 89,1\%.

2. Berdasarkan hasil uji perbadaan dua rerata menggunakan uji-t independen diperoleh nilai signifikan rerata kemampuan komunikasi matematis siswa kelas eksperimen dan kelas kontrol adalah 0,000<0,05, maka hipotesis Ho ditolak. Sehingga dapat disimpulkan bahwa rerata peningkatan kemampuan komunikasi matematis siswa yang memperoleh pembelajaran dengan Pembelajaran Matematika Realistik (PMR) lebih tinggi daripada kemampuan komunikasi matematis siswa yang memperoleh pembelajaran konvensional.

\section{UCAPAN TERIMAKASIH}

Penulis menyampaikan terimakasih kepada Bapak Arisan Candra Nainggolan, S.Pd., M.Pd. sebagai dosen pembimbing 1 dan Ibu Frida Marta Argareta Simorangkir, S.Si., M.Pd. sebagai dosen pembimbing 2 yang telah Cartesius: Jurnal Pendidikan Matematika Vol. 2, No. 1

CProdi Pendidikan Matematika Universitas Katolik Santo Thomas 
mengarahkan dan membimbing penulis mulai dari awal penelitian hingga berakhirnya penelitian sehingga penulis dapat menuliskan artikel ini yang merupakan bagian dari hasil penelitian penulis. Penulis juga menyampaikan terimakasih kepada kepala program studi Pendidikan Matematika, dekan, dan rektor Universitas Katolik Santo Thomas atas dukungan yang diberikan kepada penulis.

\section{DAFTAR PUSTAKA}

[1] A. W. P. Fujiwijaya and A. Rahman, "Analysis of Students" Communication Abilities and Mathematics Logic Thinking in Generative Learning With Scientific Approach of Class Xi Students Majoring in Health Analys At Smk Kesehatan Mega Rezky in Makassar," J. Daya Mat., Vol. 4, No. 2, pp. 218-236, 2016.

[2] S. Asnawati, "Peningkatan Kemampuan Komunikasi Matematis Siswa SMP Dengan Pembelajaran Kooperatif Tipe Teams-GamesTournaments," J. Euclid, Vol. 3, No. 2, pp. 561-567, 2017.

[3] E. Wahyuningrum, "Pengembangan Kemampuan Komunikasi Matematik Siswa SMP dengan MEAS," J. Pendidik., Vol. 14, No. 1, pp. 110, 2013.

[4] T. jamilah Syarifah, P. Sujatmiko, and R. Setiawan, "Analisis Kemampuan Komunikasi Matematis tertulis Ditinjau dari Gaya Belajar Pada Siswa Kelas XI MIPA 1 SMA Batik Surakarta Tahun Pelajaran 2015/2016," J. Pendidik. Mat. dan Mat. Solusi, Vol. 1, No. 2, pp. 1-19, 2017.

[5] Z. Arifin, D. Trapsilasiwi, and A. Fatahillah, "Analisis Kemampuan Komunikasi Matematika Dalam Menyelesaikan Masalah Pada Pokok Bahasan Sistem Persamaan Linier Dua Variabel Siswa Kelas VIII-C SMP Nuris Jember," J. Edukasi, Vol. 3, No. 2, pp. 9-12, 2016.

[6] F. Rahmawati, "Pengaruh Pendekatan Pendidikan Realistik Matematika dalam Meningkatkan Kemampuan Komunikasi Matematis Siswa Sekolah Dasar," Pros. SEMIRATA 2013. Univ. Lampung, Vol. 1, No. 1, pp. 225-238, 2013.

Cartesius: Jurnal Pendidikan Matematika Vol. 2, No. 1

CProdi Pendidikan Matematika Universitas Katolik Santo Thomas 